Article

\title{
An Investigation of the Use of Language, Social Identity and Multicultural Values for Nation-Building in Malaysian Outdoor Advertising
}

\author{
Siti Nor Amalina Ahmad Tajuddin ${ }^{1, *}$ and Noraini Zulkepli ${ }^{2}$ \\ 1 Department of Communication and Media, Faculty of Languages and Communication, \\ Sultan Idris Education University, Perak Darul Ridzuan 35900, Malaysia \\ 2 Department of English Language and Literature, Faculty of Languages and Communication, \\ Sultan Idris Education University, Perak Darul Ridzuan 35900, Malaysia; noraini@fbk.upsi.edu.my \\ * Correspondence: sitinoramalina@fbk.upsi.edu.my; Tel.: +6019-3665269
}

Received: 12 November 2018; Accepted: 7 January 2019; Published: 11 January 2019

\begin{abstract}
The mass media in the form of advertising is extensively employed in the process of nation-building in Malaysia. Advertising has been used as an important tool for educating the public about State issues, ensuring diverse cultures are equally represented and the multicultural values are emphasized to the fullest. The objective of the present study is to investigate how outdoor advertising, particularly billboards, promotes the language, social identity, and multicultural values of Malaysian society for nation-building. In Malaysia, the extensive use of advertisements has been argued as one of the most powerful mechanisms to enhance Malaysian identity, foster interactions and thus contribute to the process of nation-building even though it is portrayed in a banal and routine way. To achieve its objective, this paper utilizes semiotic methodology to examine 11 billboards to understand the relationships between texts and visuals that communicate messages to the public. The findings revealed that the billboards do not only communicate pro-social messages, but also reflect the language, social identity and multicultural values of Malaysian society towards nation-building. This study expands the work of outdoor advertising within the Malaysian society and contributes to Semiotic Analysis by examining textual-visual elements of billboards.
\end{abstract}

Keywords: nation-building; outdoor advertising; billboard; banal; language; social identity; multicultural values; semiotic analysis

\section{Introduction}

The use of mass media such as the Internet, television, radio, and newspapers can be a powerful tool for communicating not only information about products and services, but also pro-social messages (Embong et al. 2016). Billboards, posters, and banners which are referred to as outdoor advertising (Gardner et al. 2000) are also used to achieve similar purposes. The principal characteristic of outdoor advertising is 'display advertising' in the way that it can be seen and read at some distance within a few seconds to capture readers' attention (Weir 1993). Additionally, Gardner et al. (2000) suggest that 'display advertising' requires some qualities: simplicity, readability and believability in the selection of words and images to produce a convincing message.

Despite the rise of interactive digital advertising that exerts profound influences on targeted audiences (Chu and Kim 2018), outdoor billboard advertising remains an effective channel for reaching its messages to the public (Daljit 2018). The use of outdoor advertising has the potential to influence mass audience with greater exposure and repeated message viewing (Herrera and Pasch 2018). Franke and Taylor (2017) assert that despite being referred to as a traditional medium of advertising, the public still holds positive perceptions on the use of billboards. Thus, it could be argued that 
billboards still have significant impacts on influencing the mass audience. Moreover, as billboards are visible 24 hours a day and offer high reach and frequency within the targeted area, it can still have strong effects on the audience (Franke and Taylor 2017). Due to its potential to influence the mass audience, this paper focuses on the billboard, which is defined as large outdoor advertising with the ability to make a strong visual impression and often placed along busy roads and motorways (Wilson et al. 2015; Mustafa 2017). Specifically, it investigates how billboards are used as a tool for promoting language, social identity and multicultural values in Malaysia

Previous studies on billboard advertising mainly focus on the effects of food and beverages advertising (Herrera and Pasch 2018); the idea of beauty (Morris 2014); and controversial alcohol advertising (Pasch et al. 2009). The present study, however, moves beyond product and services advertising and explores how language, social identity and multicultural values communicated through billboards serve as a foundation for nation building.

As language and social identity are always associated with the idea of nation-building (Heng 2017; Ngwenya 2011), the extensive usage of government advertisements are employed to educate the public about living together in a harmonious relationship with people of different ethnic groups. The use of this mechanism is viewed as banal because other than communicating information, it is also meant to enhance the Malaysian identity, foster unity and ultimately contribute to the ideal multicultural image of a Malaysian nation. However, some scholars argue that the government advertisements are also deployed as a state mouthpiece, under-representing ethnic diversities, and promoting monolithic culture in communicating important messages to the public (Khattab 2006; Buttny and Hashim 2015). Following this line of argument, we attempt to problematize the notion of billboards produced by the government, and to illustrate how the use of language and social identity (through textual-visual elements) promote the idea of nation-building. Thus, this paper addresses the following research questions:

1. What are the textual-visual elements that are recurrently represented in billboards?

2. How are the use of language, social identity and multicultural values communicated through billboards?

\section{The Nature of Malaysian Society}

Before reviewing the relevant literature, it is important to have some background information about the Malaysian society. Malaysia is a country that has a population of approximately 32.4 million and is made up of a diverse society (Malay, Chinese, Indian, Iban, Kadazan, Orang Asli and other indigenous groups) of different languages, religion, races and cultural practices (Department of Statistics Malaysia 2018). Since its Independence in 1957, the Malay language (known as Bahasa Melayu) has become 'highly lexified' as a national language which serves as the language of instruction for mainstream education (López 2014), as well as intra-ethnic communication (John 2015).

During the 60 years of the National Front (Barisan Nasional) leadership, the political, economic and social structures of the society are still based on the British 'divide and rule' policy (Yee Mun et al. 2015). However, with the recent change of the new government ruled by the Pakatan Harapan (Alliance of Hope), the structure of the country's politics is also reformed. The vision of Pakatan Harapan government is to ensure the citizens are united as a nation through advocating the fate of the Pribumi and all Malaysians regardless of races, so that the development and economic prosperity can be shared fairly and equally by all, without being monopolized by those who are only interested in enriching themselves (Pakatan Harapan 2018).

As Malaysia is a multicultural nation, the nation-building agenda is still being pursued to ensure unity and harmonious relationships among people of different ethnic groups are sustained. Although the country is well-known for its cultural heterogeneity and is often referred to as a model for harmonious relationships, with no violent racial or religious conflicts, the emerging of ethnic tension and sensitive issues every now and then poses a significant challenge to nation-building (Yee Mun et al. 2015; Heng 2017). There are a number of reasons for this to happen. First, the nature of 
inter-ethnic relationships has continuously been seen as one ethnic group attempting to co-exist with other ethnic groups (Yee Mun et al. 2015) in the way that the sense of belonging to their ethnic group is stronger. Second, the apparent identification of ethnicity through language, physical appearance, religious and cultural practices as Malay or Chinese or Indian (Heng 2017; Yee Mun et al. 2015) marks the differences in the ethnic group's relationships. This phenomenon is transpired in everyday life.

Despite the nature of relationships between ethnic groups that is seen as 'switching on and off, alternately' (Abd Muis et al. 2012, p. 154), the Malaysian society is still able to continuously live in a 'state of stable tension' (Shamsul et al. 2014). By the 'state of stable tension', we agreed with Shamsul et al. (2014) that the nature of relationships may additionally co-exist to produce distinct patterns of social interplay between ethnic groups (for instance, the relationships can be harmonious and brittle, close and distant, and treated with respect and disregard) yet at the same time still under control and stable without having insurgences or enormous fights between ethnic groups.

\section{A Conceptual Explication}

\subsection{Language and Social Identity}

The relationship between language and social identity has long been a concern to both socio-linguistics and socio-political ideology researchers (John 2015; Noels 2014; Ngwenya 2011). Past studies have revealed that language, other than used as a tool to exchange communication and information, is a means of nation-building (John 2015; Heng 2017). In this sense, language is viewed as an instrument of cultural integration and assimilation (Noels 2014), and also a vehicle of exposing state ideology (Ahmad Tajuddin et al. 2017). Although there are many definitions that reflect the notion of social identity, the one that best fits this paper is to take individual history into account when discussing social reality. To be specific, history provides us with stories and unveils our identity as these stories tell us who we are, where we originate from and where we ought to go (Liu and Hilton 2005). History defines a direction which helps us build the essence of group identity-from where we belong to (Liu and Hilton 2005). Furthermore, social identities according to Carter (2014) can be best explained in relation to groups or categories such as (i.e., ethnic or religious groups) which allow people to create a sense of unity with others (in-group or out-group) and provide 'mutual reinforcement' during interactions. For this reason, in some countries, indicators to characterize social identities such as language, culture, race, religion, gender, political affiliation, color and geographical region (Ngwenya 2011) are employed. However, the abstract, complex, and the often-contested issue of 'who we are' or 'where we belong' in the context of a cross-cultural society continue to prevail within the society (Khattab 2006).

\subsection{Multicultural Values}

Investigating outdoor advertising in a culturally diverse society of Malaysia requires the researchers to relate the content of the messages to the multicultural values of the society. The relationships between multicultural values, 'budi bahasa' (courtesy) and culturally diverse societies are complex; multicultural values and 'budi bahasa' do not simply reflect the society of diverse ethnic groups. Rather, those values are translated into the attitude and behavior of the individual that is well mannered and courteous (Ramli 2013). Ramli (2013) further highlights that the term 'budi bahasa' and multicultural values are best referred to as 'man of culture', that explains how an individual reacts to social and cultural needs and is hence relevant within the concept of cultural appropriateness. Thus, encouraging courtesy and upholding moral values are always manifested in the government campaigns or advertising messages (Department of Prime Minister Malaysia 2010). Some examples are promoting the idea of nation-building through unity of the ethnic groups (Embong et al. 2016; Ahmad Tajuddin et al. 2017), instilling the spirit of patriotism through love for the country (Anuar 2014), and inculcating good values and shared cultural norms among ethnic groups (John 2015). These examples can therefore be argued to represent the idea of banal nationalism which will be discussed in the next section. 


\subsection{Nation-Building: Banal Nationalism?}

The term 'nation' comes with two inter-related meanings: the 'nation' as the nation-state and the people living within the state (Billig 1995). Nationalism is defined by Billig (1995) as the construction of national identity based upon the principle that people have the right to own the State. Thus, the idea of nation-building that is excessively injected into media advertising messages can have a direct or indirect influence on how these conceptions of the nation are presented. The banal nationalism theory that is introduced by Michael Billig explains how the use of national symbols such as flag and anthem represent the sense of belonging and are meant to unite people (Hummel 2017). In this way, it reflects two important meanings. First, the national symbols help to keep the everyday world as 'belonging to the world of nation-states' (Billig 2009, p. 349) in which nationality is commonly used in most of the countries to identify people (Antonsich 2016). Second, people are constantly reminded of the place and territory, or the lands of the country by presenting the national symbols (Castelló 2009; Antonsich 2016), especially through the media. The national anthem can be considered as a highly prominent national symbol and part of a powerful societal force (Hummel 2017) for nation-building. In Malaysia, for example, whenever the national anthem is sung, it is necessary to stand and sing along. As such, nation-building is an ongoing process that is close to the people: through 'banal national flagging' (Antonsich 2016), the language, the song or official documents, the labelling of the products and the media (Castelló 2009). Since this paper only analyses the billboards as outdoor advertising, the national anthem therefore, is not covered in the analysis.

\section{Methodology}

This study employed a semiotic analysis to understand the relationship between the textual-visual elements of the billboards that promote the national language, social identity, and multicultural values to the multicultural Malaysian society. Moreover, the semiotic analysis also offers an understanding of the relationship between signs and meanings (Stokes 2003) through the textual-visual elements embedded in the billboards. The signs and relations are both important concepts in the semiotic analysis (Berger 2012) because they provide "a way of relating specific texts to the system of messages in which they operate" (Stokes 2003, p. 72). For example, objects and things which are also known as 'material culture' serve as important signs that convey great information and meanings, where we can see in real life through people or in 'mass-mediated texts' such as announcements, commercials, pictures and films (Berger 2012). In this way, the semiotic analysis provides ways to understand how different elements of the texts interact with the social and cultural knowledge to produce textured meanings (Stokes 2003).

By employing semiotic analysis, it enables us to examine how meanings are produced and conveyed (Berger 2012) through the relationships between languages, words, images, and signs in visual texts (Stokes 2003), and how it reflects the notion of banal nationalism. Through the linguistic and semiotic approach, a study done by Embong et al. (2016) shows that other than the use of language, semiotic modes such as pictorial symbols, the national flag, landscape and historical sites also represent the unity of the nations through multicultural relations. In line with our earlier argument, the way the government billboards represent the idea of nation-building and foster unity is seen as banal as they become a source of reminder for the public about the homeland and national identity. Apart from analyzing the representation of semiotic modes, this paper also explores how banal nationalism operates through language and national symbols to promote nation-building to people of different ethnic groups. Our understanding of what constitutes nation-building is based on the work done by Castelló (2009) that explains how the representational elements of nation-building are displayed through media. In specific, billboards portray linguistic elements such as the use of certain phrases or slogans and symbolic elements of national as well as cultural products like flag, national anthems, buildings, or sports.

In this study, we have selected 11 billboards that promote the use of languages, social identity and multicultural values from 2013-2017 (a five-year time frame). Although there are a number of billboards within the selected period of the year, we have removed the billboards that do not meet 
the criteria of this study. In particular, the billboards that promote messages in relation to health campaigns such as Tak Nak Merokok (No smoking), Jauhi HIV/AIDS (Stay away from HIV/AIDS), Nak Sihat (Get Healthy), Hapuskan Aedes, Cegah Denggi (Remove Aedes, Prevent Dengue) and many other health-related billboards were removed. The billboards chosen from this time period were based on two criteria: first, the text and images must represent the idea of nation-building that are relevant to people of a diverse society living together as a nation. Second, the billboards must be produced by the government rather than big conglomerates such as Petronas or Telco companies in order to reflect the government agenda.

Data were collected in the form of photographs of billboards located in the side streets and along the motorway around Kuala Lumpur. All the selected billboards display the images of Malaysian people with identified ethnic groups such as Malay, Chinese, and Indians. Some billboards also present the native people of Sabah and Sarawak. The people are easily identified according to their cultural outfits: the Malay people wearing baju kurung or kebaya (female) and baju Melayu (male); the female Chinese in Cheongsam; and the female Indians in their Sarees. A national product that repeatedly appears in the billboards is the image of the country's flag either it is used as the background image or the subject in the billboard.

Adopting the semiotic analysis has helped us to understand how signs operate in the society, the multilayered images of culture, and how the portrayal of symbols and icons (Berger 2012; Stokes 2003) provides an understanding of meanings in messages that promote nation-building. Based on these features, we carefully define the object of analysis, gather the texts, describe the content and interpret them. We draw out cultural knowledge to understand and to make generalizations and conclusions of the underlying meanings of the texts (Stokes 2003). In other words, to create understanding and a sense of familiarity towards the data we meticulously interpret the idea of nation-building that constitutes in the billboards with readings and counters-readings of phrases, pictures, symbols, as well as metaphors (Ahmad Tajuddin 2017) through semiotic analysis. More importantly, all the elements in the billboards were interpreted within the specific cultural context and the notion of 'banal'. By connecting the phrases and images to the cultural context, we are able to gain a more thorough understanding of how phrases and images encapsulate and express multicultural values to symbolize the idea of nationhood.

\section{Results}

There are three themes that emerged from the semiotic analysis of the selected billboards: (1) the language of nation-building; (2) the identity of nation-building, and (3) the multicultural values of nation-building. As 'languages are the best mirror of human mind and cultures' (Gill 2014), these themes significantly reflect one's identity as the language/phrase/slogan repeatedly appears in the government PSAs. The identity of nation-building ascertains how the use of certain words and visual images can be seen as an expression of social and cultural identity of the society. The last theme (the multicultural values of nation-building) examines the good values that are attached to the people or the norm of an ethnic group that symbolizes the idea of multicultural Malaysian society. Each of the themes is further articulated as follows:

\subsection{The Language of Nation-Building}

The use of languages plays an essential role in nation-building while at the same time provides the capability of projecting different cultural identities (Gill 2014). Findings indicate that Bahasa Melayu (national language/Malay language) is the preferred language used to promote nation-building to the multicultural audiences. Incorporating Bahasa Melayu as a national language, therefore, is seen as a 'uniting symbol' for the nation irrespective of diverse ethnicities, backgrounds, cultures, and religions (Ahmad Tajuddin et al. 2017). Semiotically, what is not addressed in those billboards is the acknowledgment of other languages of the minority ethnics that are communicated in Malaysia or any encouragement for the acquisition of other languages such as Mandarin, Tamil or indigenous language, in moving towards a dynamic multicultural society. 
Moreover, one of the linguistic elements that appear repeatedly throughout the examined billboards is the use of the national slogan/phrase. For example, the use of jingles and slogans such as Perkukuhkan Perpaduan Demi Kestabilan Negara (Strengthening unity for the State stability), Aku Anak Malaysia (I am a Malaysian) demonstrate how a nation should be molded and how it would be realized in a banal manner. The use of certain repeated jingles and slogans may reinforce the recognition of the messages as they have a desirable effect in an audience's memory (Danesi 2015). As such, the power of language through jingles and slogans created to entrench the positive image of nation branding into the people's mind-set. As for the government billboards, the result is consistent with the finding in a study done by Ahmad Tajuddin et al. (2017) where the use of jingles, catchphrases, and slogans, apart from being a persuasive strategy and promotion, is also used to describe the Government's aims and intentions. For instance, the tagline Perkukuhkan Perpaduan Demi Kestabilan Negara (Strengthening unity for the State stability) provides the impression of how nation-building can be achieved through unity of the people (See Figure 1) and through the spirit of patriotism towards the country (See Figure 2) and thus exhibits a 'banalized image of the nation' (Castelló 2009, p. 309). That is, those presented images can be both close to and distant from the audience's reality. This is how the government provides banal reminders of nationhood through the language of nation-building presented in the form of jingles and slogans.

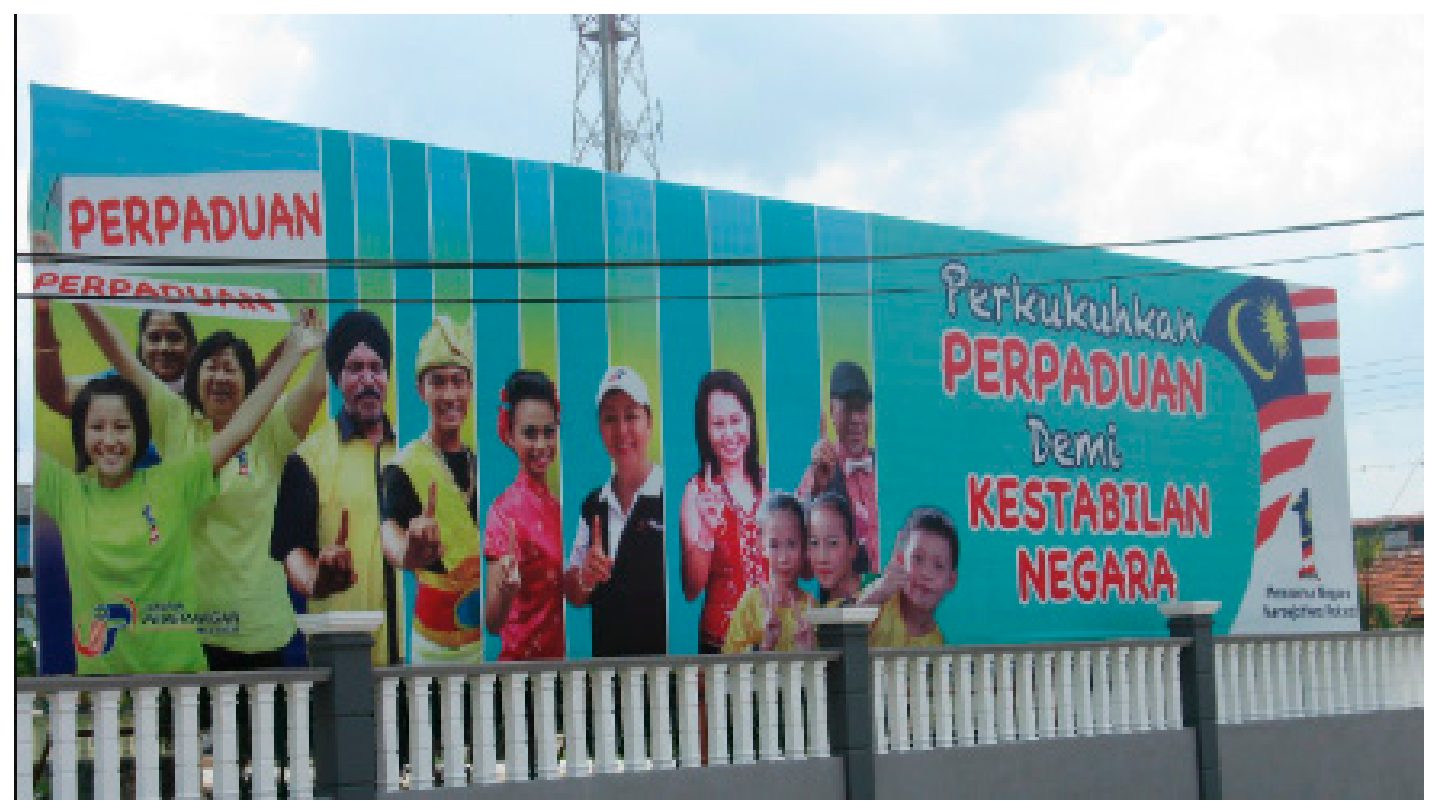

Figure 1. Perkukuhkan Perpaduan Demi Kestabilan Negara billboard.

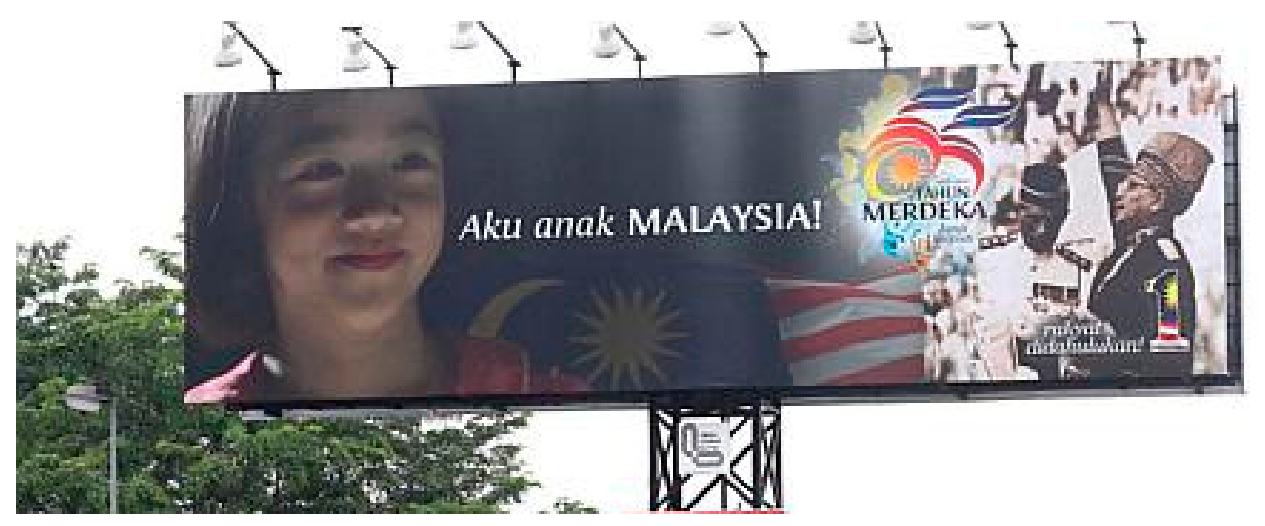

Figure 2. Aku anak Malaysia billboard. 


\subsection{The Social Identity of Nation-Building}

Analyzing the textual-visual interaction (between text and images) and its context divulges how social identity is preserved through government billboards. The indicators of social identity that are represented in the billboards not only reflect the race and culture of people of different ethnic groups (i.e., Malay, Chinese Indians, Iban, Kadazan and other ethnic minorities), through their traditional costume, their looks and color, but also political affiliation. As such, it concurs with Carter's idea of social identities which refers to an individual's group memberships and how this group membership can be shaped through the individual's participation in collective categories such as nationality, political affiliation or religion (Carter 2014). The analysis also reveals that through the recurring images of the 1 Malaysia logo (the concept that was introduced by the previous Malaysian prime minister) placed side by side with the tagline 1 Impian 1 Harapan 1 Malaysia (1 Dream 1 Hope 1 Malaysia) provide the impression of how these ideological strands seem a necessary condition for nation-building (See Figure 3). This way, the audience may naturally feel part of the messages conveyed; part of the group represented, and thus they may feel obliged to accept the government messages (Page 2016). Ideology, then, works as the representation of imaginary relationships between real things (Page 2016), and thus banalizes the reality that is imagined. The images of the children holding the flag together (Figure 3) and the background image of the flag (Figure 2) symbolize 'banal nationalism' that are used to foster social and national identity. As such, the flag is seen as an important symbol in the construction of social and national identity instilled in children since the beginning in both overt and banal ways (Billig 2009). It reflects how these symbols help to maintain unity and sense of belonging to the country and greater society.

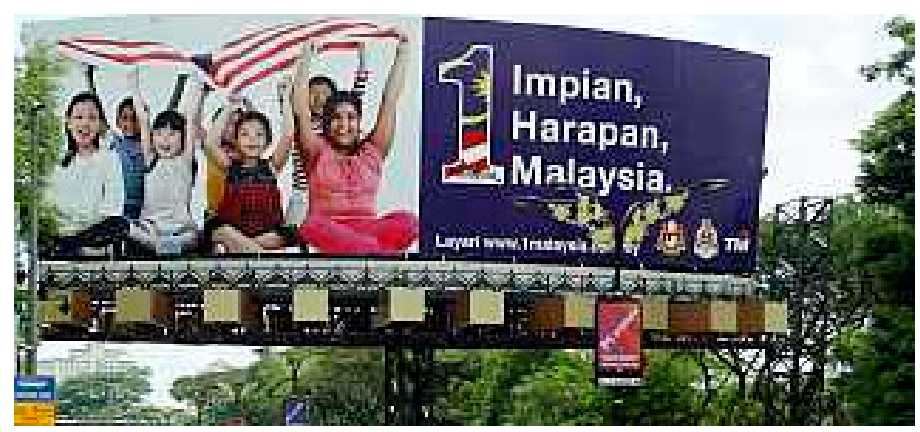

Figure 3. 1 Impian 1 Harapan 1 Malaysia billboard.

\subsection{The Multicultural Values of Nation-Building}

From the onset, there are certain values and ethics that are represented in the government billboard, including the idea of togetherness, friendly relations and respect towards each other as demonstrated in Figures 4 and 5. Moreover, the data also show that the ways people of diverse ethnic groups are represented in the government billboards are through recurrent images in which people stand beside each other (shoulder to shoulder), signifying a pleasant relationship between each ethnic group. The Malay proverb displayed on the billboard (Bersatu kita teguh, Bercerai kita roboh-United we stand, divided we fall) provides the meaning that when people are together, they are strong; however, when they are apart, they are weak. Moreover, the other two messages: Tingkatkan perpaduan antara kita (Strengthen the unity among us) and Perpaduan adalah kekuatan kita (Unity is our strength) signify how building unity and harmonious relationships among people of different ethnicities are important aspects in ensuring the stability of the country. The values and ethics that are embodied in the government billboards characterized the idea of unity in a multi-ethnic society to reflect how an individual conducts oneself following the accepted norms of a society and how he or she should behave in relation to others. The analysis of the government billboards also reveals that 'what is manifested' about the ideal nation-building is manifested through the ethnic groups' harmonious relationships, the closeness, and a dynamic interaction among them. As such, nation-building becomes 
a banal, 'unreflexive presence' in people's lives (Antonsich 2016, p. 69). The unreflexive presence that is manifested in the form of the juxtaposed image of hands with different skin color and image of children standing shoulder to shoulder shows that people are always reminded of the multicultural values through the use of analogies of bringing people together.

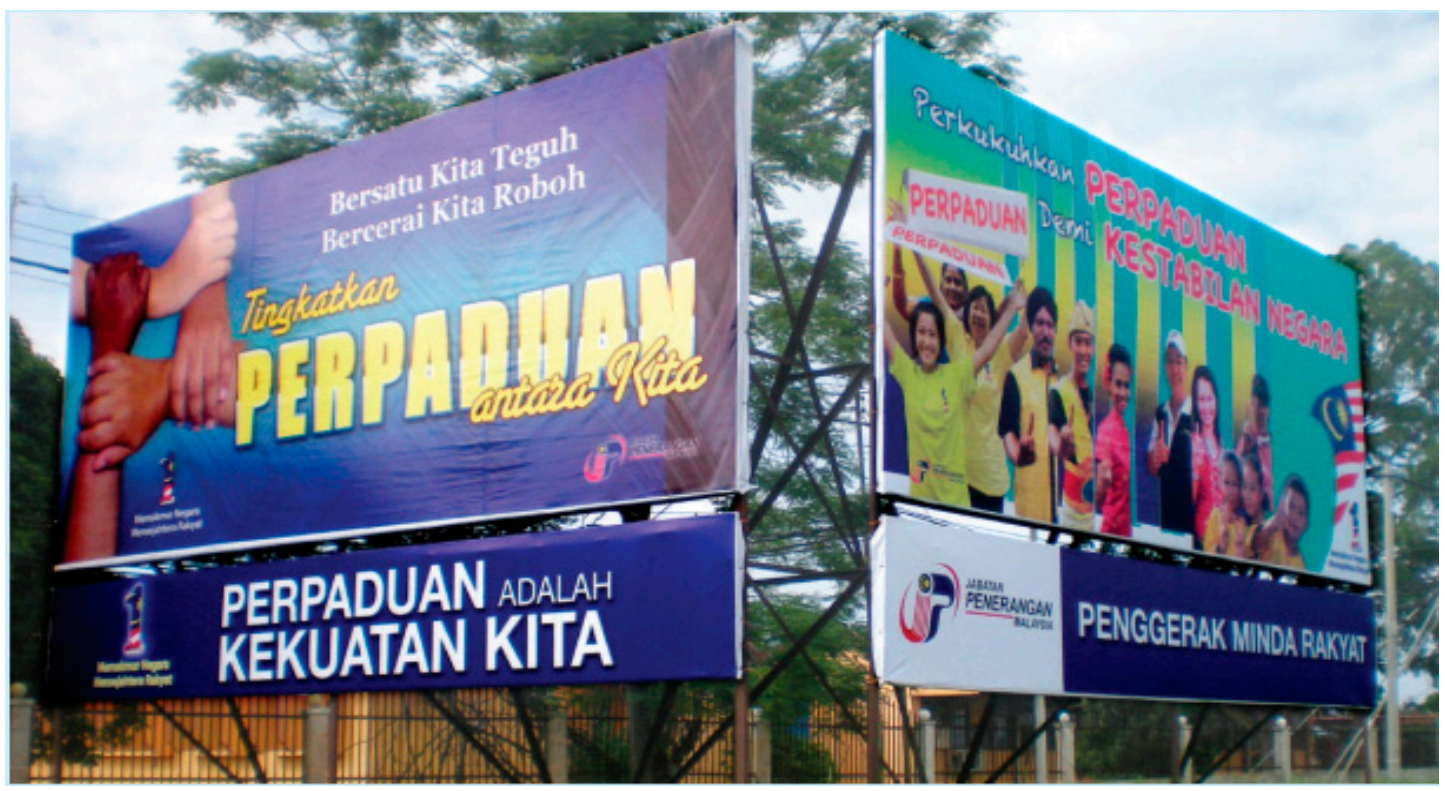

Figure 4. Some examples of multicultural values that reflect nation-building.

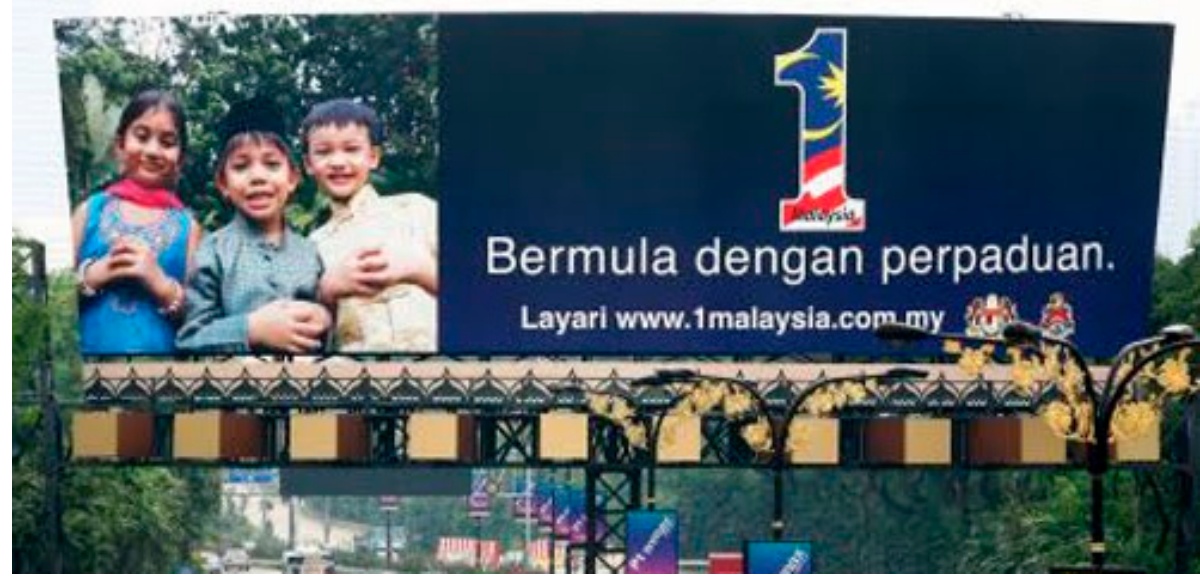

Figure 5. A living interaction between children of different groups.

\section{Conclusions}

Throughout this paper, we have examined the government billboards within the culturally diverse Malaysian society on the basis of two notions: the effort of promoting nation-building through Malaysian's outdoor advertising, and how the government PSAs reflect the use of language, social identity and multicultural values within the nation-building process. As discussed earlier, the most convincing way to understand the promotion of nation-building at work can be found in the representations of individuals of different ethnicities, repeated images, and the pleasant relationships among them, that appeared recurrently in the government billboards. The findings from the government PSAs suggest several important elements of uniting the people, such as the use of Malay language that can bring people together for a mutual understanding of meanings. What can be concluded here is the government billboards can somehow be best referred to as the 
government strategy to promote nation-building among multi-ethnic society. The main contribution of the present study is to provide a nuanced semiotic approach to the analysis of billboards, and thus extends the previous work on banal nationalism to the work of nation-building in Malaysia. Even though the contributions made in this paper can serve as a platform to understand the promotion of nation-building messages particularly to the Malaysian audience of a culturally diverse society, they will hopefully be some use to future research concentrating on how to narrow the gap between the government and major ethnic groups' interpretations on other aspects of nation-building.

Author Contributions: Writing—original draft, S.N.A.A.T.; Review, editing, and proofreading, N.Z. Both authors revised and approved the final manuscript.

Funding: This research received no external funding

Conflicts of Interest: The authors declare no conflict of interest.

\section{References}

Abd Muis, Mujibu, Badrul Azmier Mohamed, Azlan Abdul Rahman, Zaherawati Zakaria, Nazni Noordin, Jennifah Nordin, and Mahazril Aini Yaacob. 2012. Ethnic Plurality and Nation Building Process: A Comparative Analysis between Rukun Negara, Bangsa Malaysia and 1 Malaysia Concepts as Nation Building Programs in Malaysia. Asian Social Science 8: 153-60. [CrossRef]

Ahmad Tajuddin, Siti Nor Amalina. 2017. Framing in Strategic Communications: The Construction of 'National Unity' through Public Service Announcements (PSAs) in Malaysia. Ph.D. Thesis, University of Queensland, St Lucia, Brisbane, Queensland, Australia.

Ahmad Tajuddin, Siti Nor Amalina, Natalie Collie, and Yunxia Zhu. 2017. Exploring the Construction of 'National Unity ' in Malaysia: Framing Analysis of Texts and Audiences. In SHS Web of Conferences. Les Ulis: EDP Sciences, vol. 33, pp. 1-7. [CrossRef]

Antonsich, Marco. 2016. The 'Everyday' of Banal Nationalism-Ordinary People's Views on Italy and Italian. Political Geography 54: 32-42. [CrossRef]

Anuar, Mustafa K. 2014. Election Advertising in the Mainstream Print Media: Politics for Sale during Malaysia's 2013 General Election. Asia Pacific Media Educator 24: 77-94. [CrossRef]

Berger, Arthur Asa. 2012. Media Analysis Techniques. London: Sage Publications, Inc.

Billig, Michael. 1995. Banal Nationalism. London: Sage.

Billig, Michael. 2009. Reflecting on a Critical Engagement with Banal Nationalism-Reply to Skey. Sociological Review 57: 347-52. [CrossRef]

Buttny, Richard, and Azirah Hashim. 2015. Dialogue on '1 Malaysia': The Uses of Metadiscourse in Ethnopolitical Accounting. Discourse E Society 26: 147-64. [CrossRef]

Carter, Michael. 2014. Gender Socialization and Identity Theory. Social Sciences 3: 242-63. [CrossRef]

Castelló, Enric. 2009. The Nation as a Political Stage: A Theoretical Approach to Television Fiction and National Identities. International Communication Gazette 71: 303-20. [CrossRef]

Chu, Shu Chuan, and Juran Kim. 2018. The Current State of Knowledge on Electronic Word-of-Mouth in Advertising Research. International Journal of Advertising 37: 1-13. [CrossRef]

Daljit, Dhesi. 2018. The Uptrend of Outdoor Advertising. The Star Online. June 2. Available online: https://www. thestar.com.my/business/business-news/2018/06/02/the-uptrend-of-outdoor-advertising/ (accessed on 10 October 2018).

Danesi, Marcel. 2015. Advertising Discourse. The International Encyclopedia of Language and Social Interaction. [CrossRef]

Department of Prime Minister Malaysia. 2010. Government Transformation Programme; Putrajaya: The Roadmap.

Department of Statistics Malaysia. 2018. Selected Demographic Indicators Malaysia. Available online: https://www.dosm.gov.my/v1/index.php?r=column/cthemeByCat\&cat=397\&bul_id= RmsrQVZMVEh1SDR3Yng0cFRXNkxPdz09\&menu_id=L0pheU43NWJwRWVSZk1WdzQ4TlhUUT09 (accessed on 10 October 2018).

Embong, Abdul Mutalib, Juhari Sham Jusoh, Azelin Mohamed Noor, and Lee Kian Seng. 2016. A Discourse Analysis of Thematic Print Advertisements †. Global Journal of Business and Social Science Review 5: 27-36. 
Franke, George, and Charles Taylor. 2017. Public Perceptions of Billboards: A Meta-Analysis. Journal of Advertising 46: 395-410. [CrossRef]

Gardner, Rod, Sigrid Luchtenberg, and Morven Brown Building. 2000. Reference, Image, Text in German and Australian Advertising Posters. Journal of Pragmatics 32: 1807-21. [CrossRef]

Gill, Saran Kaur. 2014. Language Policy Challenges in Multi-Ethnic Malaysia. Multilingual Education 8: 17-26. [CrossRef]

Heng, Michael S. H. 2017. A Study of Nation Building in Malaysia. East Asia 34: 217-47. [CrossRef]

Herrera, Ana L., and K. E. Pasch. 2018. Targeting Hispanic Adolescents with Outdoor Food \& Beverage Advertising around Schools. Ethnicity and Health 23: 691-702. [CrossRef] [PubMed]

Hummel, Daniel. 2017. Banal Nationalism, National Anthems, and Peace. Peace Review 29: 225-30. [CrossRef]

John, Deborah Ashabai Fredericks. 2015. Language Choice and Ideology: Examining the Use of the Malay Language in English Newspaper Advertisements in Malaysia. Language \& Communication 43: 87-101. [CrossRef]

Khattab, Umi. 2006. 'Non' Mediated Images: Public Culture and (State) Television in Malaysia. International Communication Gazette 68: 347-61. [CrossRef]

Liu, James H., and Denis J. Hilton. 2005. How the Past Weighs on the Present: Social Representations of History and Their Role in Identity Politics. The British Journal of Social Psychology 44: 537-56. [CrossRef]

López, Carolina. 2014. FORUM Language Is the Soul of the Nation: Language, Education, Identity, and National Unity in Malaysia. Journal of Language, Identity, and Education 13: 217-23. [CrossRef]

Morris, Pamela K. 2014. Comparing Portrayals of Beauty in Outdoor Advertisements across Six Cultures: Bulgaria, Hong Kong, Japan, Poland, South Korea, and Turkey. Asian Journal of Communication 24: 242-61. [CrossRef]

Mustafa, K. Anuar. 2017. Under the Banner of Democracy: Political Expression in Malaysia's 13th General Election. In Election Posters Around the Globe: Political Campaigning in the Public Space. Edited by Christina Holtz-Bacha and Bengt Johansson. Cham: Springer, pp. 211-37. [CrossRef]

Ngwenya, Themba. 2011. Social Identity and Linguistic Creativity: Manifestations of the Use of Multilingualism in South African Advertising. Southern African Linguistics and Applied Language Studies 29: 1-16. [CrossRef]

Noels, Kimberly A. 2014. Language Variation and Ethnic Identity: A Social Psychological Perspective. Language E Communication 35: 88-96. [CrossRef]

Page, Janis Teruggi. 2016. Myth and Photography in Advertising: A Semiotic Analysis. Visual Communication Quarterly 1393: 90-109. [CrossRef]

Pakatan Harapan. 2018. Rebuilding Our Nation, Fulfilling Our Hope. Available online: https://kempen.s3. amazonaws.com/manifesto/Manifesto_text/Manifesto_PH_EN.pdf (accessed on 25 October 2018).

Pasch, Keryn E., Kelli A. Komro, Cheryl L. Perry, Mary O. Hearst, and Kian Farbakhsh. 2009. Does Outdoor Alcohol Advertising around Elementary Schools Vary by the Ethnicity of Students in the School? Ethnicity and Health 14: 225-36. [CrossRef] [PubMed]

Ramli, Romlah. 2013. Culturally Appropriate Communication in Malaysia: Budi Bahasa as Warranty Component in Malaysian Discourse. Journal of Multicultural Discourses 8: 65-78. [CrossRef]

Shamsul, A. Baharuddin, Yusoff, and Anis Yusal. 2014. Unity, Cohesion, Reconciliation: One Country, Three Cherished Concepts. Kuala Lumpur: Institut Terjemahan dan Buku Malaysia.

Stokes, Jane. 2003. How to Do Media and Cultural Studies. Thousand Oaks: Sage Publications Ltd.

Weir, Walter. 1993. How to Create Interest-Evoking, Sales-Inducing, Non-Irritating Advertising. New York: The Haworth Press.

Wilson, Rick T., Daniel W. Baack, and Brian D. Till. 2015. Creativity, Attention and the Memory for Brands: An Outdoor Advertising Field Study. International Journal of Advertising 34: 232-61. [CrossRef]

Yee Mun, Chin, Lee Yok Fee, Jayum Jawan, and Sarjit Singh Darshan. 2015. From Individual Choice to Collective Actions: Ethnic Consciousness in Malaysia Reconsidered. Ethnic and Racial Studies 38: 259-74. [CrossRef]

(C) 2019 by the authors. Licensee MDPI, Basel, Switzerland. This article is an open access article distributed under the terms and conditions of the Creative Commons Attribution (CC BY) license (http:/ / creativecommons.org/licenses/by/4.0/). 